\title{
Organoids as tools to investigate the molecular mechanisms of male infertility and its treatments
}

\author{
Marc Kanbar ${ }^{1,2}$, Maxime Vermeulen ${ }^{1}$ and Christine Wyns ${ }^{1,2}$ \\ ${ }^{1}$ Université catholique de Louvain, Andrology Lab, Institut de recherche clinique et expérimentale (IREC), Brussels, \\ Belgium and ${ }^{2}$ Gynecology-Andrology department, Cliniques universitaires Saint-Luc, Brussels, Belgium
}

Correspondence should be addressed to CWyns; Email: christine.wyns@uclouvain.be

\begin{abstract}
Organoids are 3D structures characterized by cellular spatial organizations and functions close to the native tissue they mimic. Attempts to create organoids originating from several tissues have now been reported, including the testis. Testicular organoids have the potential to improve our knowledge of the mechanisms that regulate testicular morphogenesis, physiology, and pathophysiology. They could especially prove as useful tools to understand the complex mechanisms involved in the regulation of the germ cell niche in infertility cases as they offer the possibility to control and modify the nature of cell types before self-assembly and thereby opening the perspective for developing innovative methods to restore fertility. To date, there are only few studies targeted at testicular organoids' formation and even less describing the generation of organoids with both testis-specific structure and function. While researchers described interesting applications with regards to testicular tissue morphogenesis and drug toxicity, further research is needed before testicular organoids would eventually lead to the generation of fertilizing spermatozoa. This review will present the conventional systems used to induce in vitro maturation of testicular cells, describe the different approaches that have been used for the development of testicular organoids and discuss the potential applications they could have in the field of male reproductive biology.

Reproduction (2021) 161 R103-R112
\end{abstract}

\section{Introduction}

Infertility nowadays occurs in 9 to $15.8 \%$ of men and can result from abnormal sperm production/transport or an ejaculation disorder (Barratt et al. 2017). Congenital urogenital pathologies such as undescended testes, genetic disorders, sequelae of infections, or medical therapies (e.g. gonadotoxic treatments), all contribute to the delay in or the absence of conception (Nieschlag \& Lenzi 2013, Barratt et al. 2017). In addition, the significant decrease $(52 \%)$ of sperm concentrations reported between 1973 and 2011 points to the emergency to identify the reasons and underlying mechanisms of this decline and subsequent male infertility (Levine et al. 2017).

Efforts to reproduce spermatogenesis ex vivo have been ongoing for more than a hundred years. Several methods of in vitro maturation of testicular cells and tissues have been evaluated (reviewed in Reuter et al. 2012), with the objective to promote the differentiation of germ cells into fertilization-competent spermatozoa. These can later be used for intracytoplasmic sperm injection to either treat infertility related to spermatogenic failure (Lee et al. 2006a, Sun et al. 2018) or to restore fertility using prepubertal testicular tissue, cryopreserved before gonadotoxic therapies (Wyns et al. 2010, Picton et al. 2015, Kanbar et al. 2020,
Wyns et al. 2020). In the specific context of testicular tissue cryopreservation before cancer treatment, in vitro maturation of spermatogonial stem cells (SSCs) present in the prepubertal testis has the advantage of circumventing the risk of disease relapse that exists when tissue or testicular cell suspensions (TCSs) contaminated with cancer cells are transplanted. Currently available methods for in vitro maturation of SSCs (within tissue fragments, as isolated seminiferous tubules or TCSs) were recently reviewed (Oliver \& Stukenborg 2020) and are summarized in Fig. 1.

Of the different in vitro maturation methods described to date, the organotypic culture technique has been the most successful in reproducing spermatogenesis ex vivo. Indeed, the birth of healthy fertile progeny has been reported in mice with sperm obtained after culture of 1 to $3 \mathrm{~mm}^{3}$ immature testicular tissue (ITT) fragments using both static and dynamic systems (Sato et al. 2011, Yokonishi et al. 2014, Komeya et al. 2016). However, less favourable outcomes have been obtained with ITT of primates (Heckmann et al. 2020) and humans (de Michele et al. 2018b, Medrano et al. 2018, Portela et al. 2019). Only one study on human ITT reported the reproduction of the meiotic process (de Michele et al. 2018b) albeit with an extremely poor efficiency that did not allow to fully characterize the generated haploid cells. 


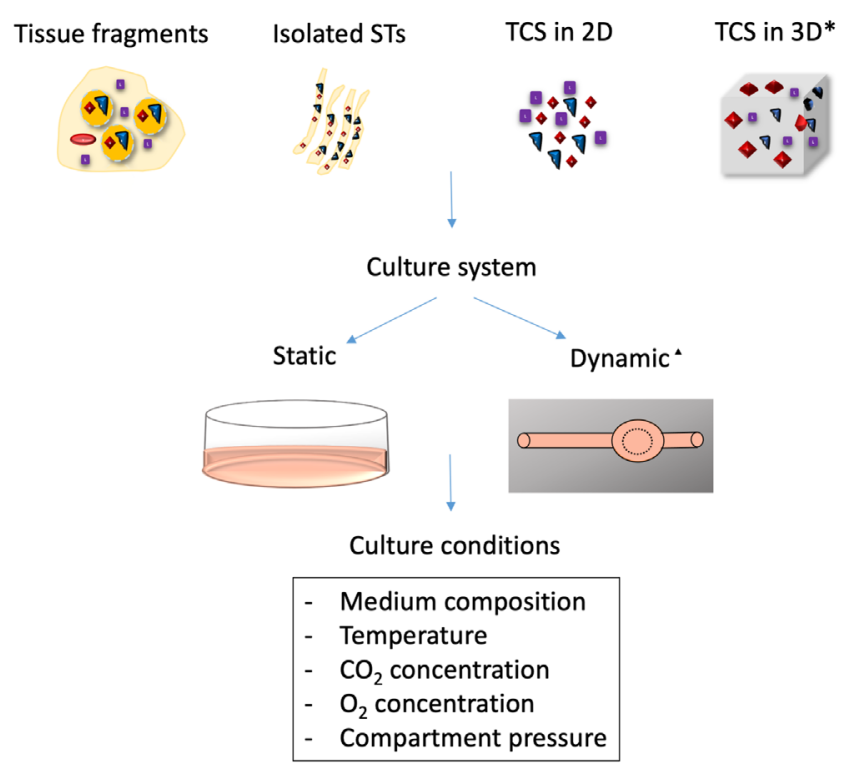

Figure 1 Different available options for germ cell in vitro maturation from intact or disaggregated testicular tissue. *: with or without scaffold - including testicular organoids; $\mathbf{~ : ~ M i c r o f l u i d i c , ~ s h a k i n g / ~}$ rotating culture or shaken bioreactors; ST: seminiferous tubule; TCS: testicular cell suspension.

While 2D-cell culture was the first technique used for in vitro maturation of TCSs, the completion of spermatogenesis starting from prepubertal TCSs was only achieved in cattle and rodents, but the generated haploid cells were either abnormal or incompletely characterized (Izadyar et al. 2003, Iwanami et al. 2006, Xie et al. 2010). Attempts to culture adult human TCSs were previously reported but were either not reproducible (Tesarik et al. 1999), not suitable for clinical application due to the use of animal components (Cremades et al. 1999, Sousa et al. 2002), or did not demonstrate any germ cell differentiation despite some cellular reorganization (von Kopylow et al. 2018). The absence of a proper spatial arrangement of the testicular cells was assumed to be a major factor to explain failed in vitro maturation in 2D culture (Reuter et al. 2014, Stukenborg et al. 2018).

Hence, researchers turned their efforts to 3D-cell culture systems which were able to better mimic the in vivo cell configuration required for more physiologic cellular responses (Petersen et al. 1992, Bissell et al. 2002) and normal germ cell differentiation (Stukenborg et al. 2009). Scaffold-free (e.g. hanging drops, cellular aggregates) or scaffold-based (e.g. hydrogel, decellularized ECM) approaches were both considered (Edmondson et al. 2014).

Limited meiotic progression was noted with the scaffold-free approach (Yokonishi et al. 2013), leading to the use of scaffold-based approaches in most of the available studies.

While many of these studies did not investigate germ cell development or failed to obtain post-meiotic cells (Hadley et al. 1985, Gassei et al. 2006, 2010, Reda et al. 2014, Reuter et al. 2014, Zhang et al. 2014, 2017, Vermeulen et al. 2018), haploid germ cells were eventually generated in systems using various natural and synthetic scaffolds (Table 1).

Overall, compared to the 2D system, improved cell organization and viability were observed (reviewed in Richer et al. 2020). Most importantly, human round spermatids able to fertilize mice oocytes were obtained in a Matrigel ${ }^{\mathrm{TM}}$-based culture system (Sun et al. 2018). Unfortunately, despite some encouraging results, the efficiency of spermatogenesis in 3D culture systems remained low with a limited recapitulation of the testisspecific architecture.

Paralleling these developments, the concept of organoids was added to the field of 3D culture (reviewed in Velasco et al. 2020). Although definitions varied since the 1950s, an organoid was eventually defined as 'a unit of function of a given organ that can reproduce, in culture, a biological structure similar in

Table 1 Most commonly used scaffolds in 3D culture of testicular cells reporting germ cell differentiation up to the haploid stage.

\begin{tabular}{|c|c|c|}
\hline Scaffolds & Species & Reference \\
\hline \multicolumn{3}{|l|}{ Natural } \\
\hline \multicolumn{3}{|l|}{ ECM-derived scaffolds } \\
\hline Collagen & Rat & Lee et al. (2006b) \\
\hline \multirow[t]{2}{*}{ Matrigel ${ }^{\mathrm{TM}} *$} & Rat & Lee et al. (2006b), Legendre et al. (2010) \\
\hline & Humans ${ }^{\wedge}$ & Sun et al. (2018) \\
\hline Decellularized $\mathrm{ECM}^{+}$ & Humans ${ }^{\wedge}$ & Ashouri Movassagh et al. (2020) \\
\hline \multicolumn{3}{|l|}{ Seaweed-derived scaffolds } \\
\hline Alginate & Mouse & Baert et al. (2019) \\
\hline Soft-Agarose & Mouse & Stukenborg et al. (2008), Stukenborg et al. (2009), Abu Elhija et al.. (2012) \\
\hline \multicolumn{3}{|r|}{ 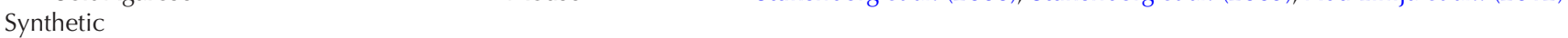 } \\
\hline PLGA & Rat & Lee et al. (2011) \\
\hline \multirow[t]{3}{*}{ Methylcellulose } & Mouse & Stukenborg et al. (2009) \\
\hline & Rhesus monkey & Huleihel et al. (2015) \\
\hline & Humans ${ }^{\wedge}$ & Abofoul-Azab et al. (2019) \\
\hline
\end{tabular}

*Extracted from mice Engelbreth-Holm-Swarm tumour cells and mainly composed of laminin, collagen IV, and entactin (Hughes et al. 2010); ${ }^{\dagger}$ solid or solubilized form; All reports used prepubertal testicular tissue except studies marked with $\mathrm{a}^{\wedge}$ that used adult tissue.

ECM, extracellular matrix; PLGA, Poly (lactic-co-glycolic acid). 
architecture and function to its counterpart in vivo' (Simian \& Bissell 2017).

The potential of organoid technology to accurately mimic biological structures in vitro, as already demonstrated for numerous animal and human organs (e.g. lung, liver, pancreas fallopian tube) (reviewed in Kim et al. 2020), was recently extended to the testis.

This review, therefore, aims at first to present the different approaches that have so far been applied to generate testicular organoids (TOs), secondly to analyse how far research has progressed with achieving in vitro spermatogenesis by using TO culture, and thirdly to highlight the scientific advances made to understand testicular morphogenesis and (patho-)physiology. Eventually, the numerous applications that TOs could offer in the field of male reproduction in the future will be discussed.

\section{Testicular organoid generation}

Several groups recently attempted to generate TOs in both animals and humans (see Tables 2 and 3 respectively). The first group to introduce the term 'testicular organoid' studied the culture of human pubertal TCSs on adult decellularized testicular tissue slices. The study showed that adult human TCSs were able to self-organize whether a decellularized tissue scaffold was present or not. Despite the lack of the typical native tissue architecture (expected in a proper organoid), spermatogonia and their important niche cells were maintained for 1 month in vitro. Leydig and Sertoli cell functionalities were demonstrated by the respective detection of testosterone and inhibin $\mathrm{B}$ in culture supernatants (Baert et al. 2017). This inability of adult Sertoli cells to reorganize into cords was also reported when cultured onto prepubertal porcine decellularized ITT scaffolds (Vermeulen et al. 2018).

The first time testicular organoids were shown to harbour seminiferous-tubule-like structures with an accurate cell configuration was when TCSs from prepubertal rats (5-8 and 20 days old) were spread on several layers of Matrigel ${ }^{\mathrm{TM}}$ (Alves-Lopes et al. 2017). Consistent with the previous studies, the use of pubertal (60-days-old rats) TCSs did not lead to the formation of seminiferous-tubule-like structures, suggesting that only immature TCSs can.

Using a hanging drop co-culture system followed by the culture of cell clusters on low attachment plates, somatic (immortalized Leydig cells and Sertoli cells) and germ cells, from adult men, were also unable to rearrange properly although a medium enriched with a solubilized form of testicular ECM was used (Pendergraft et al. 2017).

In contrast to all the studies using immature tissue, an abnormal cell reorganization was observed when TCSs isolated from prepubertal pigs were cultured in microwell centrifugal aggregation plates to generate the
TOs. Germ cells and Sertoli cells were both located at the outer side, while Leydig and endothelial cells were found on the inner side (Sakib et al. 2019). Although the exact architecture of the native organ was not obtained, two distinct compartments separated by a basement membrane were established. This led to an attenuated response to retinoic acid (RA) compared to $2 \mathrm{D}$ culture, suggesting that the cellular interactions modulated the response to RA similarly to that in vivo (Endo et al. 2017). Interestingly, application of the protocol to mice, rhesus macaques, and human prepubertal TCSs resulted in the formation of TO-like structures with a similar organization, suggesting that the system can be applied to all mammalian TCSs (Sakib et al. 2019).

Eventually, in large mammals, the first TOs to have an accurate tissue-specific structure were obtained in 2019 by Vermeulen et al. (2019). TCSs from prepubertal pigs were cultured in collagen and in a solubilized form of decellularized testicular tissue. Germ cells and Sertoli cells were located inside the tubule-like structures and surrounded by a basement membrane while both peritubular and Leydig cells were located on the outside. However, regardless of the matrix, the number of germ cells decreased, and their differentiation was limited to the stage of spermatocytes during the 45 days culture period. This suggests that either cell-cell interactions/ assembly (required for germ cell differentiation) were not identical to the native organ, or that the culture environment (media composition and conditions) was unsuitable.

Several factors have been shown to influence TO formation. Self-assembly of testicular cells appeared to be age-dependent as observed in rats (Alves-Lopes et al. 2017). This observation was further confirmed in a recent study in mice, where organoid formation was either absent or delayed when peripubertal vs prepubertal TCSs were used. Also, when the same protocol was applied to adult murine and human TCSs, no cellular self-assembly was observed (Edmonds \& Woodruff 2020). Interestingly, immature cells (and not their secreted factors) were able to rescue the assembly of adult cells when co-cultured together, suggesting that one or several cell types (e.g. immature Sertoli cells) in prepubertal TCSs can drive TO assembly (Edmonds \& Woodruff 2020).

The cell density of the TCS also seemed to play a role in TO formation. Notably, it was shown that immature TCSs used at high concentration or after centrifugation as a cell pellet formed seminiferous-tubule-like structures, regardless of the addition of an ECM-based hydrogel when cultured at the air-liquid interphase (Yokonishi et al. 2013, Zhang et al. 2014, Vermeulen et al. 2019). The benefit of high cell density was further highlighted by an improved organization of rat TOs generated in Matrige $^{\mathrm{TM}}$ when higher cell concentrations were used (Alves-Lopes et al. 2017).

The need for a supportive scaffold or ECM components for TO formation is unclear as most studies were not 


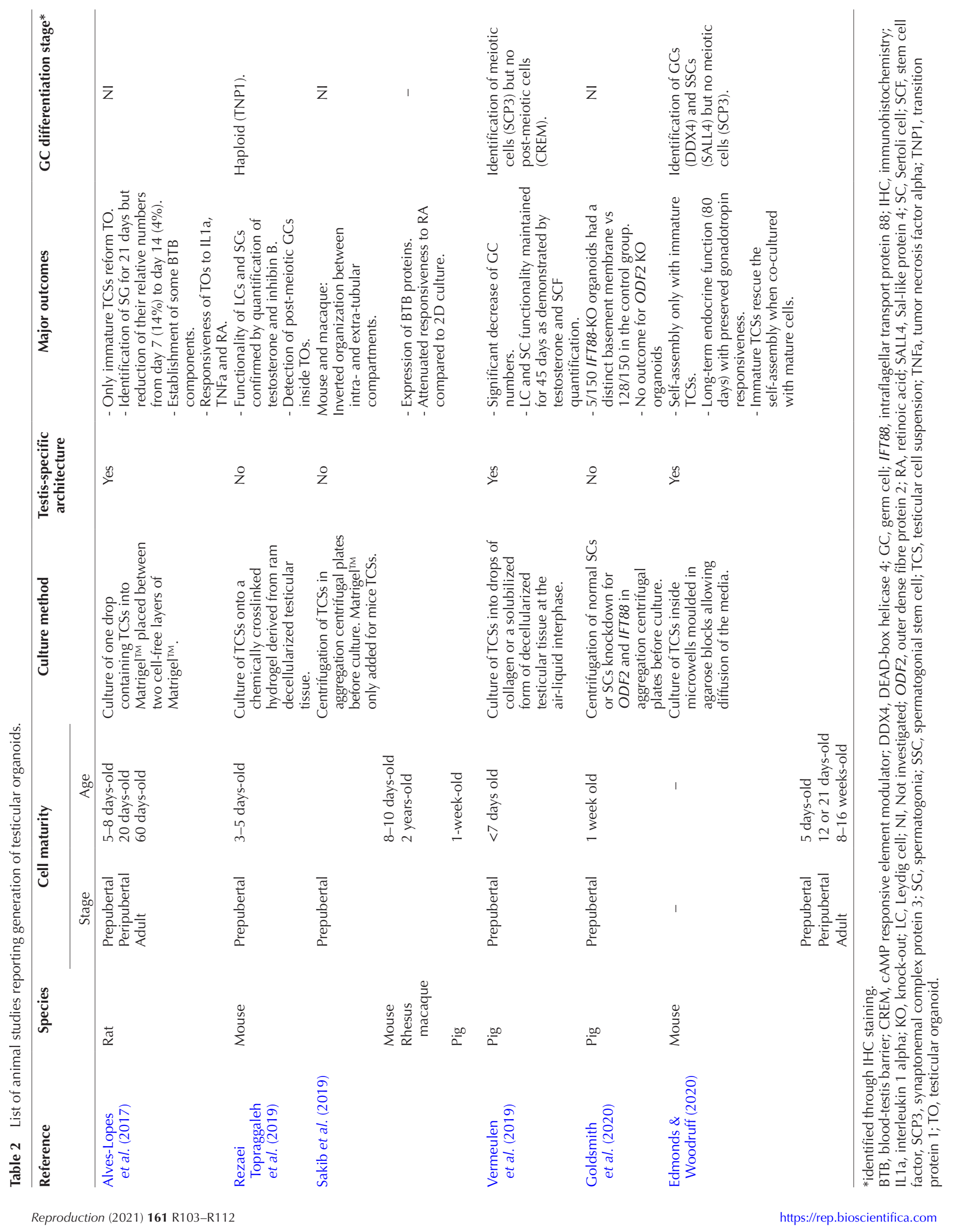


designed to answer this question or it led to controversial results. Indeed, ECM-derived hydrogels were used in four studies to generate human (Pendergraft et al. 2017), porcine (Vermeulen et al. 2019), rat (Alves-Lopes et al. 2017), and murine (Rezaei Topraggaleh et al. 2019) TOs, but the absence of a control group without hydrogel prevented drawing any conclusion regarding the benefit of the ECM-hydrogel for TO development. Only two studies compared the impact of the presence/absence of ECM compounds (Matrige $\mathrm{T}^{\mathrm{TM}}$ ) on prepubertal mice TO formation. The first demonstrated that TCSs failed to form organoids when Matrigel ${ }^{\mathrm{TM}}$ was absent (Sakib et al. 2019), by contrast with the second where organized and functional TOs were obtained without any Matrigel ${ }^{\mathrm{TM}}$ supplementation (Edmonds \& Woodruff 2020). It is thus still not clear in which conditions the endogenous production of ECM components by the TCSs (Maekawa et al. 1996) would be sufficient to promote TO formation and in which conditions the addition of a testis-specificECM-component would be required.

The ratio of different testicular cell types could be another factor to influence TO assembly, similarly to what happens during gonadogenesis where the number of Sertoli cells predetermines the size of the germ and Leydig cell populations of the adult testis (Rebourcet et al. 2017). Using different germ and somatic stem cell ratios to generate, TOs could therefore prove useful in determining the optimal conditions for cell assembly.

\section{TOs as tools to study testicular morphogenesis and pathophysiology}

TOs could serve as a tool to evaluate the role of different factors or cell types in testicular morphogenesis and physiology.

The utility of theTO model to understand the molecular mechanisms involved in testicular development was first highlighted in the study of Alves-Lopes et al. where an impaired formation of TOs was observed after exposure to interleukin 1 alpha (IL-1a) and TNF 1 alpha (TNF1a) (Alves-Lopes et al. 2017). These observations were in line with those made in vivo where the injection of IL-1a and TNF alpha (TNFa) led to the disruption or destabilization of the blood-testis barrier (BTB), respectively (Sarkar et al. 2008, Cheng \& Mruk 2012).

The main advantage of TOs is that the testicular cells can be sorted and selected enabling the modification of a cell of interest or its replacement by another cell before cell assembly (Fig. 2A).

For instance, TO-like structures were recently used to study the role of primary cilia (present on testicular somatic cells) in testicular morphogenesis (Goldsmith et al. 2020). Indeed, following inhibition of primary cilia assembly, through CRISPR Cas9-mediated gene editing of a structural component of primary cilia and siRNAmediated gene silencing of a functional component of the intraflagellar transport system in isolated porcine
Sertoli cells, the authors observed an abnormal cellular assembly and organization compared to controls.

The assembly of testicular cells either originating from different individuals (e.g. genetically normal and abnormal), modified using gene-editing techniques, or exposed to external factors (e.g. drugs, toxins) may help in understanding the molecular mechanisms involved in testicular dysfunction. While immunofluorescent labelling of testicular cells before TO formation proved useful to study the cellular organization in TOs (Pendergraft et al. 2017), genetic transgene integration of fluorescent proteins (e.g. GFP or mCherry) in cell types of interest would be required for longer-term studies of TO formation (Fig. 2A).

Moreover, TOs could help improve our knowledge of the roles of different cell types within the testicular microenvironment. For example, endothelial cells (Bhang et al. 2018) and testicular macrophages (DeFalco et al. 2015) were both recently identified as important players in the SSC niche regulation. Developing TOs enriched with or lacking one or more cell types (Fig. 2B) could therefore prove useful in understanding their exact roles in testicular pathophysiology.

Disease modelling could represent another application of TOs allowing both the study of the disease itself and the development of patient-tailored treatments, as described in organoids from various tissue types (Fatehullah et al. 2016). Notably, TOs can be potentially generated with TCSs isolated from patients suffering from infertility conditions such as Klinefelter syndrome, early maturation arrest, cryptorchidism, or testicular cancer. The generated disease-modelling TOs could then be compared under different conditions with TOs developed with cells from fertile/healthy men and used as an assay for subsequent evaluation of a candidate therapeutic agent. In this regard, TOs were already recently used as models to study drug toxicity (chemotherapeutic agents: busulfan, doxorubicin, cisplatin, and etoposide) (Pendergraft et al. 2017) and also to assess the impact of environmental toxins (phthalate derivatives) (Sakib et al. 2019) and microbiological agents (Zika virus) (Strange et al. 2018) on the testis in vitro. In the future, human TOs could be a promising and improved alternative to animal models for pharmaceutical drug development and testing.

\section{TOs as a tool to restore fertility}

TOs could be generated with TCSs isolated from ITT of prepubertal patients affected by haematological cancers (Fig. 2C) with the objective of creating an artificial testis free of cancer cells that can be transplanted back to the cured patient. Indeed, cryopreservation of ITT before potential gonadotoxic treatment is now ethically accepted in several centres (Wyns et al. 2011, Picton et al. 2015, Valli-Pulaski et al. 2019, Kanbar et al. 2020). Autotransplantation of the tissue back to patients after treatment completion is considered a promising method 
Table 3 List of human studies reporting generation of testicular organoids.

\begin{tabular}{|c|c|c|c|c|c|c|}
\hline \multirow[b]{2}{*}{ Reference } & \multicolumn{2}{|l|}{ Cell maturity } & \multirow[b]{2}{*}{ Culture method } & \multirow[b]{2}{*}{$\begin{array}{l}\text { Testis-specific } \\
\text { architecture }\end{array}$} & \multirow[b]{2}{*}{ Major outcomes } & \multirow[b]{2}{*}{$\begin{array}{l}\text { GC differentiation } \\
\text { stage* }\end{array}$} \\
\hline & Stage & Age & & & & \\
\hline $\begin{array}{l}\text { Baert et al. } \\
(2017)\end{array}$ & Peripubertal & $\begin{array}{l}15 \text { years } \\
\text { old }\end{array}$ & $\begin{array}{l}\text { Culture of TCSs onto agar } \\
\text { blocks or decellularized } \\
\text { adult testicular tissue slices. }\end{array}$ & No & $\begin{array}{l}\text { Maintenance of SG and } \\
\text { Somatic cells for } 1 \text { month. } \\
\text { LC and SC functionality } \\
\text { confirmed by quantification } \\
\text { of testosterone and inhibin B. }\end{array}$ & $\mathrm{NI}$ \\
\hline $\begin{array}{l}\text { Pendergraft et al. } \\
\text { (2017) }\end{array}$ & Adult & $\begin{array}{l}56-61 \\
\text { years old }\end{array}$ & $\begin{array}{l}\text { Culture of GCs together with } \\
\text { immortalized LCs and SCs } \\
\text { within a media enriched } \\
\text { with a solubilized form of } \\
\text { decellularized testicular } \\
\text { tissue into hanging drop } \\
\text { plates for } 48 \text { h and } \\
\text { transferred to ultra-low } \\
\text { attachment plates. }\end{array}$ & No & $\begin{array}{l}\text { LC functionality confirmed by } \\
\text { testosterone quantification. } \\
\text { Transition of a small } \\
\text { percentage of GC from the } \\
\text { diploid to the haploid stage. }\end{array}$ & Haploid $^{+}$ \\
\hline $\begin{array}{l}\text { Strange et al. } \\
(2018)\end{array}$ & Adult & $\mathrm{N} / \mathrm{A}$ & $\begin{array}{l}\text { Culture of SG together with } \\
\text { primary LCs and SCs within } \\
\text { a media enriched with a } \\
\text { solubilized form of } \\
\text { decellularized testicular } \\
\text { tissue into hanging drop } \\
\text { plates for } 48 \text { h and } \\
\text { transferred to ultra-low } \\
\text { attachment plates. }\end{array}$ & No & $\begin{array}{l}\text { Reduced viability in TOs } \\
\text { infected by the Zika virus as } \\
\text { shown by a decrease of the } \\
\text { ATP production/TO. } \\
\text { Reduced expression of } \\
\text { markers of SSCs (ZBTB16), } \\
\text { SCs and LCs (CYP19A1, } \\
\text { STAR) in infected TOs. }\end{array}$ & $\mathrm{NI}$ \\
\hline $\begin{array}{l}\text { Sakib et al. } \\
(2019)\end{array}$ & Prepubertal & $\begin{array}{l}6 \text { month } \\
\text { old and } 5 \\
\text { years old }\end{array}$ & $\begin{array}{l}\text { Centrifugation of TCSs in } \\
\text { aggregation centrifugal } \\
\text { plates before culture. }\end{array}$ & No & $\begin{array}{l}\text { Inverted organization between } \\
\text { intra- and extra-tubular } \\
\text { compartments. }\end{array}$ & $\mathrm{NI}$ \\
\hline
\end{tabular}

*identified through IHC staining; + protamine- 1 and acrosin.

CYP19A1, cytochrome P450 family 19 subfamily A member 1; GC, germ cell; IHC, immunohistochemistry; LC, Leydig cell; N/A, no information about the age of the patients; NI, Not investigated; SC, Sertoli cell; SG, spermatogonia; SSC, spermatogonial stem cell; STAR, steroidogenic acute regulatory protein; TCS, testicular cell suspension; TO, testicular organoid; ZBTB16, zinc finger and BTB domain containing protein 16.

to restore their fertility. The birth of a healthy baby monkey after ICSI using autograft-derived spermatozoa was the proof of the concept (Fayomi et al. 2019). However, infiltration of the testis by malignant cells can occur in up to $21 \%$ of young boys affected by leukaemia (Kim et al. 1986). Hence, elimination of cancer cells before organoid generation with either cell-sorting techniques (Dovey et al. 2013) or with specific culture protocols (Sadri-Ardekani et al. 2014) could be applied to eliminate the risk of cancer cell reintroduction. Once the safety and efficacy of such protocols are proven, TOs created with the selected decontaminated cells could then be considered for transplantation. This has the advantage of exposing TOs to the in vivo macroenvironment, including blood-circulating factors, required for spermatogenesis (de Michele et al. 2017b).

No studies have evaluated the grafting of TOs so far although human cerebral organoids were shown to survive and re-vascularize after xenotransplantation to the mouse (Mansour et al. 2018). Knowledge of the real potential of a TO environment to support germ cell differentiation is thus still lacking.

\section{Remaining challenges with TOs}

As only immature TCSs were shown to possess the ability to reorganize with a testis-specific architecture
(Alves-Lopes et al. 2017, Edmonds \& Woodruff 2020), a major challenge will be to create TOs harbouring this specific organization with cells from adults presenting with testicular failure. This issue can be circumvented by creating $\mathrm{TO}$ chimeras by co-culture of immature and adult TCSs as recently demonstrated in mice (Edmonds \& Woodruff 2020), although access to immature human Sertoli cells may be difficult for evident ethical reasons. However, Sertoli cells generated from patient-derivedinduced pluripotent stem cells (iPSCs) (Rodriguez Gutierrez et al. 2018) could represent an interesting alternative to drive the assembly of adult TOs offering a new way to study infertility in adult males (Fig. 2D).

Organoids could increase the reproductive potential of ITT fragments as a fertility restoration strategy (Table 4). Most notably, their production can be non-time limited and in high numbers, if coupled to efficacious cell expansion protocols. However, while the culture of entire tissue pieces already allowed the completion of spermatogenesis and generation of offspring in mice (Sato et al. 2011), research groups who reported on the formation of TOs from prepubertal tissue paid more attention to their architecture and somatic cell functionalities rather than germ cell differentiation. A major problem resides in the difficulty to maintain germ cells in vitro and in achieving their differentiation as was reported by several groups working with TOs (Vermeulen et al. 2019, Edmonds 

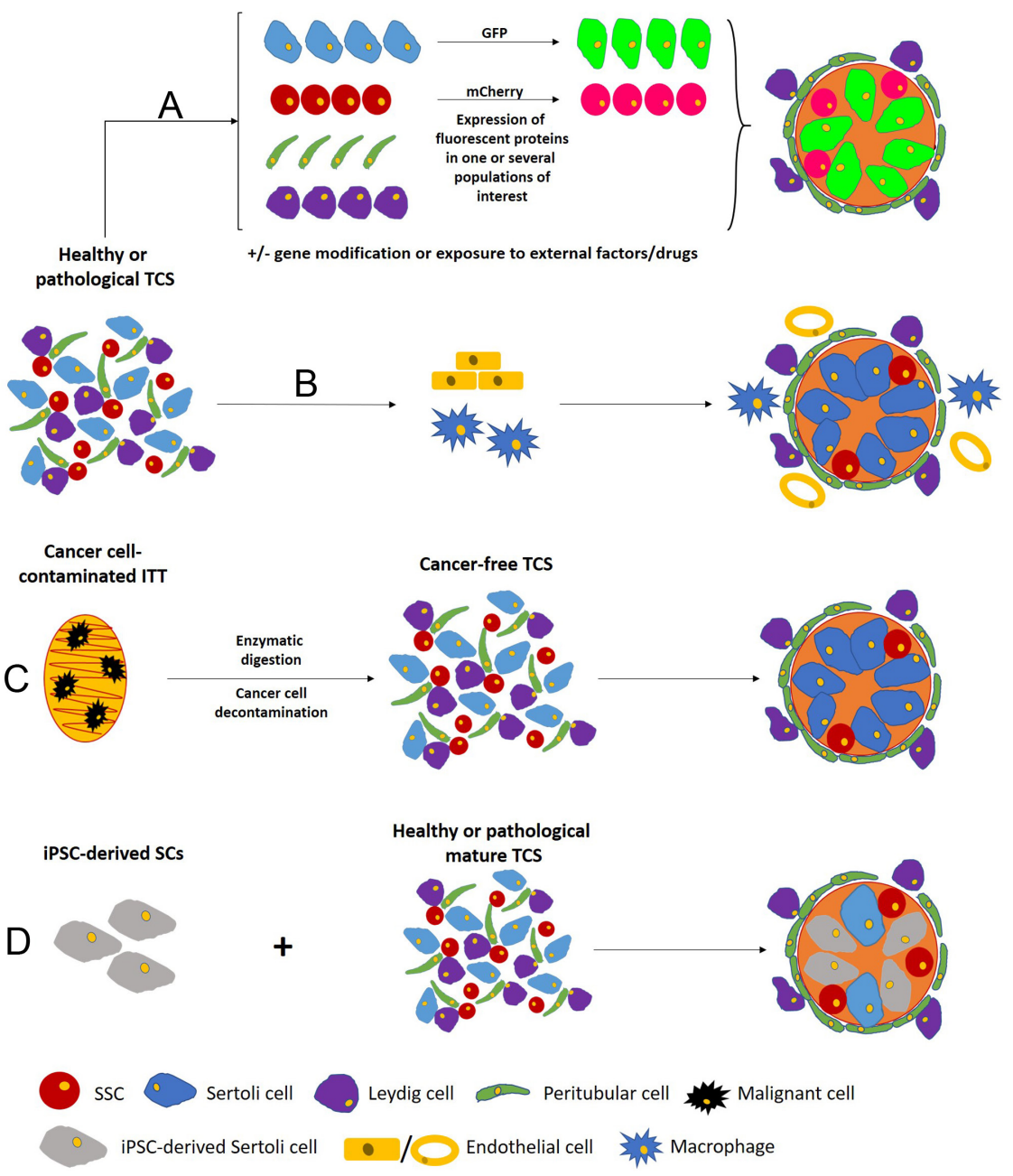

Figure 2 Potential application of TOs. (A) TCSs isolated from pathological testicular tissue (e.g. testicular cancer, Klinefelter syndrome, maturation arrest, etc.) used to generate TOs and compare their cellular organization and functionalities to healthy TOs. Genetic modifications to induce expression of fluorescent proteins in one or several populations of interest in healthy TCSs or to explore gene defects (e.g. through CRISPRCas9 technology) and monitor the role of each cell type in testicular morphogenesis. (B) TOs used to study the role of cell types (e.g. testicular endothelial cells and testicular macrophages) involved in the regulation of the GC niche. (C) In the case of contamination of ITT by malignant cells (e.g. in the case of leukaemia, lymphoma, metastasizing cancers), TOs are generated following specific decontamination and used for in vitro maturation or in vivo transplantation. (D) Considering the limited access to ITT for research purposes and the inability of adult SCs to drive TO self-assembly, immature SC-like cells could be generated from iPSCs and mixed with adult TCSs, either healthy or pathological, to promote the generation of chimera TOs. Cas9, CRISPR associated protein 9; CRISPR, clustered regularly interspaced short palindromic repeats; GC, germ cell; GFP, green fluorescent protein; iPSC, induced pluripotent stem cell; ITT, immature testicular tissue; IVM, in vitro maturation; SC, Sertoli cell; SSC, spermatogonial stem cell; TCS, testicular cell suspension; TO, testicular organoid.
\& Woodruff 2020). Indeed, in rodent TOs, germ cells differentiated until the spermatid stage in one report (Rezaei Topraggaleh et al. 2019), while other groups reported no differentiation (Edmonds \& Woodruff 2020) or did not include this outcome in their studies (Alves-Lopes et al. 2017, Sakib et al. 2019). In non-rodent mammalian TOs, germ cell differentiation was reported but either with very low efficiency (Pendergraft et al. 2017) or restricted to the spermatocyte stage (Vermeulen et al. 2019).

These limited results in terms of spermatogenesis efficiency, especially with regard to larger mammals and primates, are mainly due to the general lack of knowledge on media components needed to reproduce spermatogenesis in vitro (de Michele et al. 2017a, de Michele et al. 2018a,b, Heckmann et al. 2020). However, as studies at the genome level during testis development, puberty, and adulthood (Hermann et al. 2018, Guo et al. 2020) start to unravel the cues and signals required for tubule morphogenesis up to the differentiation of germ cells, it is expected that optimal culture media components will be identified.

Sequential culture systems that provide the required growth factors specific to each stage of TO development (Vermeulen et al. 2019) coupled to microfluidic systems providing specific concentration gradients (e.g. required to maintain a balance between stem cell self-renewal and differentiation) (Fatehullah et al. 2016) might contribute to the achievement of a faithful reproduction of the testis ex vivo.

\section{Conclusion and perspectives}

We are still in the early stages of TO formation with substantial room for improvement when addressing the numerous challenges and perspectives. TOs with structure and function closely mimicking those of the native tissue will highly likely serve as a powerful tool to study testis development, regulating mechanisms of the germ cell niche, and testicular disorders, including those leading to infertility. These are the key to developing successful methods for SSC-based therapy. Moreover, the capacity to produce self-renewing TOs in high numbers, with the possibility of modifying cell types before testicular cells' self-assembly, will greatly contribute to the understanding of the respective roles of each testicular cell-subpopulation.

As vast heterogeneity was observed in both the protocols for TO generation and TOs morphological/ 
Table 4 Advantages and limitations of human testicular organoids compared to immature testicular tissue (ITT) fragments.

\begin{tabular}{|c|c|c|}
\hline & Organoid & ITT fragment \\
\hline $\begin{array}{l}\text { Physiological cells communication and } \\
\text { adhesion/cohesion }\end{array}$ & $\mathrm{No}^{+}$ & Yes \\
\hline Possibility of large-scale production & Yes & No \\
\hline $\begin{array}{l}\text { Possibility to be vascularized in vivo and } \\
\text { in vitro }\end{array}$ & Yes* & Yes \\
\hline Long-term maintenance in vitro & $\mathrm{Yes}^{\ddagger}$ & Yes* \\
\hline Possibility of genetic modification & Yes & No \\
\hline Possibility to be cryopreserved and stored & Yes & Yes \\
\hline $\begin{array}{l}\text { Potential to restore spermatogenesis when } \\
\text { niche is damaged }\end{array}$ & Yes & No \\
\hline $\begin{array}{l}\text { Potential for safe use for fertility } \\
\text { restoration in cases of haematological or } \\
\text { metastasizing diseases }\end{array}$ & Yes & $\mathrm{No}^{p}$ \\
\hline
\end{tabular}

tpartially, to be further explored; *Both in vivo (Mansour et al. 2018) and in vitro (through tissue engineering) (Grebenyuk \& Ranga 2019) are possible but have so far not been applied to the testis; ${ }^{*} 12$ weeks in mice; *6 months in mice; $\mathbb{P}$ only in the absence of malignant cell contamination.

functional features among studies, it is of prime importance to develop standardized protocols to ensure the reproducibility and comparability of future research outcomes on TOs.

Finally, the prospect of combining organoid technology with new bioengineering techniques (e.g. bioprinting, microfluidics), as was already attempted with double-cell constructs in alginate (Baert et al. 2019) or multi-organ-on-a-chip (Baert et al. 2020) (also referred to as assembloids) (Marton \& Pasca 2020), holds promise in developing integral study models of spermatogenesis.

\section{Declaration of interest}

The authors declare that there is no conflict of interest that could be perceived as prejudicing the impartiality of the research reported.

\section{Funding}

Some of the studies cited in this review were supported by grants from the Fonds National de la Recherche Scientifique de Belgique (grant Télévie No. 7451016F and 7650818), the foundation Salus Sanguinis and Belgian foundation against cancer (FDC 2016-141).

\section{Authors contribution statement}

$M K$ and MV performed the literature search and wrote the manuscript, CW performed critical revision of the manuscript and approved the final version.

\section{References}

Abofoul-Azab M, Lunenfeld E, Levitas E, Zeadna A, Younis JS, Bar-Ami S \& Huleihel M 2019 Identification of premeiotic, meiotic, and postmeiotic cells in testicular biopsies Without sperm from Sertoli cell-only syndrome patients. International Journal of Molecular Sciences 20 470. (https://doi. org/10.3390/ijms20030470)
Abu Elhija M, Lunenfeld E, Schlatt S \& Huleihel M 2012 Differentiation of murine male germ cells to spermatozoa in a soft agar culture system. Asian Journal of Andrology 14 285-293. (https://doi.org/10.1038/ aja.2011.112)

Alves-Lopes JP, Soder O \& Stukenborg JB 2017 Testicular organoid generation by a novel in vitro three-layer gradient system. Biomaterials 130 76-89. (https://doi.org/10.1016/j.biomaterials.2017.03.025)

Ashouri Movassagh S, Ashouri Movassagh S, Banitalebi Dehkordi M, Pourmand G, Gholami K, Talebi A, Esfandyari S, Jabari A, Samadian A \& Abbasi M 2020 Isolation, identification and differentiation of human spermatogonial cells on three-dimensional decellularized sheep testis. Acta Histochemica 122 151623. (https://doi.org/10.1016/j.acthis.2020.151623)

Baert Y, De Kock J, Alves-Lopes JP, Soder O, Stukenborg JB \& Goossens E 2017 Primary human testicular cells self-organize into organoids with testicular properties. Stem Cell Reports 8 30-38. (https://doi. org/10.1016/j.stemcr.2016.11.012)

Baert Y, Dvorakova-Hortova K, Margaryan H \& Goossens E 2019 Mouse in vitro spermatogenesis on alginate-based 3D bioprinted scaffolds. Biofabrication 11 035011. (https://doi.org/10.1088/1758-5090/ab1452)

Baert Y, Ruetschle I, Cools W, Oehme A, Lorenz A, Marx U, Goossens E \& Maschmeyer I 2020 A multi-organ-chip co-culture of liver and testis equivalents: a first step toward a systemic male reprotoxicity model. Human Reproduction 35 1029-1044. (https://doi.org/10.1093/humrep/deaa057)

Barratt CLR, Bjorndahl L, De Jonge CJ, Lamb DJ, Osorio Martini F, McLachlan R, Oates RD, van der Poel S, St John B, Sigman M et al. 2017 The diagnosis of male infertility: an analysis of the evidence to support the development of global WHO guidance-challenges and future research opportunities. Human Reproduction Update 23 660680. (https://doi.org/10.1093/humupd/dm×021)

Bhang DH, Kim BJ, Kim BG, Schadler K, Baek KH, Kim YH, Hsiao W, Ding BS, Rafii S, Weiss MJ et al. 2018 Testicular endothelial cells are a critical population in the germline stem cell niche. Nature Communications 9 4379. (https://doi.org/10.1038/s41467-018-06881-z)

Bissell MJ, Radisky DC, Rizki A, Weaver VM \& Petersen OW 2002 The organizing principle: microenvironmental influences in the normal and malignant breast. Differentiation; Research in Biological Diversity 70 537-546. (https://doi.org/10.1046/j.1432-0436.2002.700907.x)

Cheng CY \& Mruk DD 2012 The blood-testis barrier and its implications for male contraception. Pharmacological Reviews 64 16-64. (https://doi. org/10.1124/pr.110.002790)

Cremades N, Bernabeu R, Barros A \& Sousa M 1999 In-vitro maturation of round spermatids using co-culture on Vero cells. Human Reproduction 14 1287-1293. (https://doi.org/10.1093/humrep/14.5.1287)

de Michele F, Poels J, Giudice MG, De Smedt F, Ambroise J, Vermeulen M, Gruson D \& Wyns C 2018a In vitro formation of the blood-testis barrier during long-term organotypic culture of human prepubertal tissue: comparison with a large cohort of pre/peripubertal boys. Molecular Human Reproduction 24 271-282 .(https://doi.org/10.1093/molehr/gay012)

de Michele F, Poels J, Vermeulen M, Ambroise J, Gruson D, Guiot Y \& Wyns C 2018b Haploid germ cells generated in organotypic culture of testicular tissue From prepubertal boys. Frontiers in Physiology 91413. (https://doi.org/10.3389/fphys.2018.01413)

de Michele F, Poels J, Weerens L, Petit C, Evrard Z, Ambroise J, Gruson D \& Wyns C 2017a Preserved seminiferous tubule integrity with spermatogonial survival and induction of Sertoli and Leydig cell maturation after long-term organotypic culture of prepubertal human testicular tissue. Human Reproduction 32 32-45. (https://doi. org/10.1093/humrep/dew300)

de Michele F, Vermeulen M \& Wyns C 2017b Fertility restoration with spermatogonial stem cells. Current Opinion in Endocrinology, Diabetes, and Obesity 24 424-431. (https://doi.org/10.1097/ MED.0000000000000370)

DeFalco T, Potter SJ, Williams AV, Waller B, Kan MJ \& Capel B 2015 Macrophages contribute to the spermatogonial niche in the adult testis. Cell Reports 12 1107-1119. (https://doi.org/10.1016/j. celrep.2015.07.015)

Dovey SL, Valli H, Hermann BP, Sukhwani M, Donohue J, Castro CA, Chu T, Sanfilippo JS \& Orwig KE 2013 Eliminating malignant contamination from therapeutic human spermatogonial stem cells. Journal of Clinical Investigation 123 1833-1843. (https://doi.org/10.1172/JCI65822)

Edmonds ME \& Woodruff TK 2020 Testicular organoid formation is a property of immature somatic cells, which self-assemble and exhibit 
long-term hormone-responsive endocrine function. Biofabrication 12 045002. (https://doi.org/10.1088/1758-5090/ab9907)

Edmondson R, Broglie JJ, Adcock AF \& Yang L 2014 Three-dimensional cell culture systems and their applications in drug discovery and cell-based biosensors. Assay and Drug Development Technologies 12 207-218. (https://doi.org/10.1089/adt.2014.573)

Endo T, Freinkman E, de Rooij DG \& Page DC 2017 Periodic production of retinoic acid by meiotic and somatic cells coordinates four transitions in mouse spermatogenesis. PNAS 114 E10132-E10141. (https://doi. org/10.1073/pnas.1710837114)

Fatehullah A, Tan SH \& Barker N 2016 Organoids as an in vitro model of human development and disease. Nature Cell Biology 18 246-254. (https://doi.org/10.1038/ncb3312)

Fayomi AP, Peters K, Sukhwani M, Valli-Pulaski H, Shetty G, Meistrich ML, Houser L, Robertson N, Roberts V, Ramsey C et al. 2019 Autologous grafting of cryopreserved prepubertal rhesus testis produces sperm and offspring. Science 363 1314-1319. (https://doi.org/10.1126/science.aav2914)

Gassei K, Ehmcke J, Dhir R \& Schlatt S 2010 Magnetic activated cell sorting allows isolation of spermatogonia from adult primate testes and reveals distinct GFRa1-positive subpopulations in men. Journal of Medical Primatology 39 83-91. (https://doi.org/10.1111/j.16000684.2009.00397.x)

Gassei K, Schlatt S \& Ehmcke J 2006 De novo morphogenesis of seminiferous tubules from dissociated immature rat testicular cells in xenografts. Journal of Andrology 27 611-618. (https://doi.org/10.2164/ jandrol.05207)

Goldsmith TM, Sakib S, Webster D, Carlson DF, Van der Hoorn F \& Dobrinski I 2020 A reduction of primary cilia but not hedgehog signaling disrupts morphogenesis in testicular organoids. Cell and Tissue Research 380 191-200. (https://doi.org/10.1007/s00441-019-03121-8)

Grebenyuk S \& Ranga A 2019 Engineering organoid vascularization. Frontiers in Bioengineering and Biotechnology 7 39. (https://doi. org/10.3389/fbioe.2019.00039)

Guo J, Nie X, Giebler M, Mlcochova H, Wang Y, Grow EJ, DonorConnect, Kim R, Tharmalingam M, Matilionyte G et al. 2020 The dynamic transcriptional cell atlas of testis development during human puberty. Cell Stem Cell 26 262-276.e4. (https://doi.org/10.1016/j.stem.2019.12.005)

Hadley MA, Byers SW, Suarez-Quian CA, Kleinman HK \& Dym M 1985 Extracellular matrix regulates Sertoli cell differentiation, testicular cord formation, and germ cell development in vitro. Journal of Cell Biology 101 1511-1522. (https://doi.org/10.1083/jcb.101.4.1511)

Heckmann L, Langenstroth-Rower D, Wistuba J, Portela JMD, van Pelt AMM, Redmann K, Stukenborg JB, Schlatt S \& Neuhaus N 2020 The initial maturation status of marmoset testicular tissues has an impact on germ cell maintenance and somatic cell response in tissue fragment culture. Molecular Human Reproduction 26 374-388. (https://doi. org/10.1093/molehr/gaaa024)

Hermann BP, Cheng K, Singh A, Roa-De La Cruz L, Mutoji KN, Chen IC, Gildersleeve H, Lehle JD, Mayo M, Westernstroer B et al. 2018 The mammalian spermatogenesis single-cell transcriptome, from spermatogonial stem cells to spermatids. Cell Reports 25 1650-1667.e8. (https://doi.org/10.1016/j.celrep.2018.10.026)

Hughes CS, Postovit LM \& Lajoie GA 2010 Matrigel: a complex protein mixture required for optimal growth of cell culture. Proteomics $\mathbf{1 0}$ 1886-1890. (https://doi.org/10.1002/pmic.200900758)

Huleihel M, Nourashrafeddin S \& Plant TM 2015 Application of threedimensional culture systems to study mammalian spermatogenesis, with an emphasis on the rhesus monkey (Macaca mulatta). Asian Journal of Andrology 17 972-980. (https://doi.org/10.4103/1008-682X.154994)

Iwanami Y, Kobayashi T, Kato M, Hirabayashi M \& Hochi S 2006 Characteristics of rat round spermatids differentiated from spermatogonial cells during co-culture with Sertoli cells, assessed by flow cytometry, microinsemination and RT-PCR. Theriogenology 65 288-298. (https:// doi.org/10.1016/j.theriogenology.2005.04.025)

Izadyar F, Den Ouden K, Creemers LB, Posthuma G, Parvinen M \& De Rooij DG 2003 Proliferation and differentiation of bovine type A spermatogonia during long-term culture. Biology of Reproduction 68 272-281. (https://doi.org/10.1095/biolreprod.102.004986)

Kanbar M, de Michele F, Giudice MG, Desmet L, Poels J \& Wyns C 2020 Long-term follow-up of boys who have undergone a testicular biopsy for fertility preservation. Human Reproduction 36 26-39. (https://doi. org/10.1093/humrep/deaa281)
Kim J, Koo BK \& Knoblich JA 2020 Human organoids: model systems for human biology and medicine. Nature Reviews: Molecular Cell Biology 21 571-584. (https://doi.org/10.1038/s41580-020-0259-3)

Kim TH, Hargreaves HK, Chan WC, Brynes RK, Alvarado C, Woodard J \& Ragab AH 1986 Sequential testicular biopsies in childhood acute lymphocytic leukemia. Cancer 57 1038-1041. (https://doi.org/10.1002/1097-0142(19860301)57:5<1038::aidcncr2820570527>3.0.co;2-1)

Komeya M, Kimura H, Nakamura H, Yokonishi T, Sato T, Kojima K, Hayashi K, Katagiri K, Yamanaka H, Sanjo H et al. 2016 Long-term ex vivo maintenance of testis tissues producing fertile sperm in a microfluidic device. Sci Rep 21472, 21472. Scientific Reports 621472. (https://doi.org/10.1038/srep21472)

Lee DR, Kim KS, Yang YH, Oh HS, Lee SH, Chung TG, Cho JH, Kim HJ, Yoon TK \& Cha KY 2006a Isolation of male germ stem cell-like cells from testicular tissue of non-obstructive azoospermic patients and differentiation into haploid male germ cells in vitro. Human Reproduction 21 471-476. (https://doi.org/10.1093/humrep/dei319)

Lee JH, Kim HJ, Kim H, Lee SJ \& Gye MC 2006b In vitro spermatogenesis by three-dimensional culture of rat testicular cells in collagen gel matrix. Biomaterials 27 2845-2853. (https://doi.org/10.1016/j. biomaterials.2005.12.028)

Lee JH, Oh JH, Lee JH, Kim MR \& Min CK 2011 Evaluation of in vitro spermatogenesis using poly(D,L-lactic-co-glycolic acid) (PLGA)-based macroporous biodegradable scaffolds. Journal of Tissue Engineering and Regenerative Medicine 5 130-137. (https://doi.org/10.1002/term.297)

Legendre A, Froment P, Desmots S, Lecomte A, Habert R \& Lemazurier E 2010 An engineered 3D blood-testis barrier model for the assessment of reproductive toxicity potential. Biomaterials 31 4492-4505. (https://doi. org/10.1016/j.biomaterials.2010.02.029)

Levine $\mathrm{H}$, Jorgensen $\mathrm{N}$, Martino-Andrade A, Mendiola J, Weksler-Derri D, Mindlis I, Pinotti R \& Swan SH 2017 Temporal trends in sperm count: a systematic review and meta-regression analysis. Human Reproduction Update 23 646-659. (https://doi.org/10.1093/humupd/dmx022)

Maekawa M, Kamimura K \& Nagano T 1996 Peritubular myoid cells in the testis: their structure and function. Archives of Histology and Cytology 59 1-13. (https://doi.org/10.1679/aohc.59.1)

Mansour AA, Goncalves JT, Bloyd CW, Li H, Fernandes S, Quang D, Johnston S, Parylak SL, Jin X \& Gage FH 2018 An in vivo model of functional and vascularized human brain organoids. Nature Biotechnology 36 432-441. (https://doi.org/10.1038/nbt.4127)

Marton RM \& Pasca SP 2020 Organoid and assembloid technologies for investigating cellular crosstalk in human brain development and disease. Trends in Cell Biology 30 133-143. (https://doi.org/10.1016/j. tcb.2019.11.004)

Medrano JV, Vilanova-Perez T, Fornes-Ferrer V, Navarro-Gomezlechon A, Martinez-Triguero ML, Garcia S, Gomez-Chacon J, Povo I, Pellicer A, Andres $\mathbf{M M}$ et al. 2018 Influence of temperature, serum, and gonadotropin supplementation in short- and long-term organotypic culture of human immature testicular tissue. Fertility and Sterility 110 1045-1057.e3. (https://doi.org/10.1016/j.fertnstert.2018.07.018)

Nieschlag E \& Lenzi A 2013 The conventional management of male infertility. International Journal of Gynaecology and Obstetrics 123(Supplement 2) S31-S35. (https://doi.org/10.1016/j.ijgo.2013.09.001)

Oliver E \& Stukenborg JB 2020 Rebuilding the human testis in vitro. Andrology 8 825-834. (https://doi.org/10.1111/andr.12710)

Pendergraft SS, Sadri-Ardekani H, Atala A \& Bishop CE 2017 Threedimensional testicular organoid: a novel tool for the study of human spermatogenesis and gonadotoxicity in vitro. Biology of Reproduction 96 720-732. (https://doi.org/10.1095/biolreprod.116.143446)

Petersen OW, Ronnov-Jessen L, Howlett AR \& Bissell MJ 1992 Interaction with basement membrane serves to rapidly distinguish growth and differentiation pattern of normal and malignant human breast epithelial cells. PNAS 89 9064-9068. (https://doi.org/10.1073/pnas.89.19.9064)

Picton HM, Wyns C, Anderson RA, Goossens E, Jahnukainen K, Kliesch S Mitchell RT, Pennings G, Rives N, Tournaye H et al. 2015 A European perspective on testicular tissue cryopreservation for fertility preservation in prepubertal and adolescent boys. Human Reproduction 30 2463-2475. (https://doi.org/10.1093/humrep/dev190)

Portela JMD, de Winter-Korver CM, van Daalen SKM, Meissner A, de Melker AA, Repping S \& van Pelt AMM 2019 Assessment of fresh and cryopreserved testicular tissues from (pre)pubertal boys during organ 
culture as a strategy for in vitro spermatogenesis. Human Reproduction 34 2443-2455. (https://doi.org/10.1093/humrep/dez180)

Rebourcet D, Darbey A, Monteiro A, Soffientini U, Tsai YT, Handel I, Pitetti JL, Nef S, Smith LB \& O'Shaughnessy PJ 2017 Sertoli cell number defines and predicts germ and Leydig cell population sizes in the adult mouse testis. Endocrinology 158 2955-2969. (https://doi.org/10.1210/en.2017-00196)

Reda A, Hou M, Landreh L, Kjartansdottir KR, Svechnikov K, Soder O \& Stukenborg JB 2014 In vitro spermatogenesis - optimal culture conditions for testicular cell survival, germ cell differentiation, and steroidogenesis in rats. Frontiers in Endocrinology 5 21. (https://doi. org/10.3389/fendo.2014.00021)

Reuter K, Ehmcke J, Stukenborg JB, Simoni M, Damm OS, Redmann K, Schlatt S \& Wistuba J 2014 Reassembly of somatic cells and testicular organogenesis in vitro. Tissue and Cell 46 86-96. (https://doi. org/10.1016/j.tice.2013.12.001)

Reuter K, Schlatt S, Ehmcke J \& Wistuba J 2012 Fact or fiction: in vitro spermatogenesis. Spermatogenesis 2 245-252. (https://doi.org/10.4161/ spmg.21983)

Rezaei Topraggaleh T, Rezazadeh Valojerdi M, Montazeri L \& Baharvand H 2019 A testis-derived macroporous 3D scaffold as a platform for the generation of mouse testicular organoids. Biomaterials Science 7 1422-1436. (https://doi.org/10.1039/c8bm01001c)

Richer G, Baert Y \& Goossens E 2020 In-vitro spermatogenesis through testis modelling: toward the generation of testicular organoids. Andrology 8 879-891. (https://doi.org/10.1111/andr.12741)

Rodriguez Gutierrez D, Eid W \& Biason-Lauber A 2018 A human gonadal cell model from induced pluripotent stem cells. Frontiers in Genetics $\mathbf{9}$ 498. (https://doi.org/10.3389/fgene.2018.00498)

Sadri-Ardekani H, Homburg CH, van Capel TM, van den Berg $\mathrm{H}$, van der Veen F, van der Schoot CE, van Pelt AM \& Repping S 2014 Eliminating acute lymphoblastic leukemia cells from human testicular cell cultures: a pilot study. Fertility and Sterility 101 1072-1078.e1. (https://doi. org/10.1016/j.fertnstert.2014.01.014)

Sakib S, Uchida A, Valenzuela-Leon P, Yu Y, Valli-Pulaski H, Orwig K, Ungrin M \& Dobrinski I 2019 Formation of organotypic testicular organoids in microwell culturedagger. Biology of Reproduction $\mathbf{1 0 0}$ 1648-1660. (https://doi.org/10.1093/biolre/ioz053)

Sarkar O, Mathur PP, Cheng CY \& Mruk DD 2008 Interleukin 1 alpha (IL1A) is a novel regulator of the blood-testis barrier in the rat. Biology of Reproduction 78 445-454. (https://doi.org/10.1095/ biolreprod.107.064501)

Sato T, Katagiri K, Gohbara A, Inoue K, Ogonuki N, Ogura A, Kubota Y \& Ogawa T 2011 In vitro production of functional sperm in cultured neonatal mouse testes. Nature 471 504-507. (https://doi.org/10.1038/ nature09850)

Simian M \& Bissell MJ 2017 Organoids: a historical perspective of thinking in three dimensions. Journal of Cell Biology 216 31-40. (https://doi. org/10.1083/jcb.201610056)

Sousa M, Cremades N, Alves C, Silva J \& Barros A 2002 Developmental potential of human spermatogenic cells co-cultured with Sertoli cells. Human Reproduction 17 161-172. (https://doi.org/10.1093/ humrep/17.1.161)

Strange DP, Zarandi NP, Trivedi G, Atala A, Bishop CE, Sadri-Ardekani H \& Verma S 2018 Human testicular organoid system as a novel tool to study Zika virus pathogenesis. Emerging Microbes and Infections 7 82. (https:// doi.org/10.1038/s41426-018-0080-7)

Stukenborg JB, Jahnukainen K, Hutka M \& Mitchell RT 2018 Cancer treatment in childhood and testicular function: the importance of the somatic environment. Endocrine Connections 7 R69-R87. (https://doi. org/10.1530/EC-17-0382)

Stukenborg JB, Schlatt S, Simoni M, Yeung CH, Elhija MA, Luetjens CM, Huleihel M \& Wistuba J 2009 New horizons for in vitro spermatogenesis? An update on novel three-dimensional culture systems as tools for meiotic and post-meiotic differentiation of testicular germ cells. Molecular Human Reproduction 15 521-529. (https://doi.org/10.1093/molehr/gap052)

Stukenborg JB, Wistuba J, Luetjens CM, Elhija MA, Huleihel M, Lunenfeld E, Gromoll J, Nieschlag E \& Schlatt S 2008 Coculture of spermatogonia with somatic cells in a novel three-dimensional softagar-culture-system. Journal of Andrology 29 312-329. (https://doi. org/10.2164/jandrol.107.002857)

Sun $M$, Yuan Q, Niu M, Wang H, Wen L, Yao C, Hou J, Chen Z, Fu H, Zhou $\mathbf{F}$ et al. 2018 Efficient generation of functional haploid spermatids from human germline stem cells by three-dimensional-induced system. Cell Death and Differentiation 25 749-766. (https://doi.org/10.1038/ s41418-017-0015-1)

Tesarik J, Bahceci M, Ozcan C, Greco E \& Mendoza C 1999 Restoration of fertility by in-vitro spermatogenesis. Lancet 353 555-556. (https://doi. org/10.1016/S0140-6736(98)04784-9)

Valli-Pulaski H, Peters KA, Gassei K, Steimer SR, Sukhwani M, Hermann BP, Dwomor L, David S, Fayomi AP, Munyoki SK et al. 2019 Testicular tissue cryopreservation: 8 years of experience from a coordinated network of academic centers. Human Reproduction 34 966-977. (https://doi. org/10.1093/humrep/dez043)

Velasco V, Shariati SA \& Esfandyarpour R 2020 Microtechnology-based methods for organoid models. Microsystems and Nanoengineering 676. (https://doi.org/10.1038/s41378-020-00185-3)

Vermeulen M, Del Vento F, de Michele F, Poels J \& Wyns C 2018 Development of a cytocompatible scaffold from pig immature testicular tissue allowing human Sertoli cell attachment, proliferation and functionality. International Journal of Molecular Sciences 19227. (https://doi.org/10.3390/ijms19010227)

Vermeulen M, Del Vento F, Kanbar M, Pyr Dit Ruys S, Vertommen D, Poels J \& Wyns C 2019 Generation of organized porcine testicular organoids in solubilized hydrogels from decellularized extracellular matrix. International Journal of Molecular Sciences 20 5476. (https://doi. org/10.3390/ijms20215476)

von Kopylow K, Schulze W, Salzbrunn A, Schaks M, Schafer E, Roth B, Schlatt S \& Spiess AN 2018 Dynamics, ultrastructure and gene expression of human in vitro organized testis cells from testicular sperm extraction biopsies. Molecular Human Reproduction 24 123-134. (https://doi.org/10.1093/molehr/gax070)

Wyns C, Curaba M, Petit S, Vanabelle B, Laurent P, Wese JF \& Donnez J 2011 Management of fertility preservation in prepubertal patients: 5 years' experience at the Catholic University of Louvain. Human Reproduction 26 737-747. (https://doi.org/10.1093/humrep/deq387)

Wyns C, Curaba M, Vanabelle B, Van Langendonckt A \& Donnez J 2010 Options for fertility preservation in prepubertal boys. Human Reproduction Update 16 312-328. (https://doi.org/10.1093/humupd/dmp054)

Wyns C, Kanbar M, Giudice MG \& Poels J 2020 Fertility preservation for prepubertal boys: lessons learned from the past and update on remaining challenges towards clinical translation. Human Reproduction Update In press. (doi:10.1093/humupd/dmaa050)

Xie B, Qin Z, Huang B, Xie T, Yao H, Wei Y, Yang X, Shi D \& Jiang H 2010 In vitro culture and differentiation of buffalo (Bubalus bubalis) spermatogonia. Reproduction in Domestic Animals 45 275-282. (https:// doi.org/10.1111/j.1439-0531.2008.01281.x)

Yokonishi T, Sato T, Katagiri K, Komeya M, Kubota Y \& Ogawa T 2013 In vitro reconstruction of mouse seminiferous tubules supporting germ cell differentiation. Biology of Reproduction 89 15. (https://doi.org/10.1095/ biolreprod.113.108613)

Yokonishi T, Sato T, Komeya M, Katagiri K, Kubota Y, Nakabayashi K, Hata K, Inoue K, Ogonuki N, Ogura A et al. 2014 Offspring production with sperm grown in vitro from cryopreserved testis tissues. Nature Communications 5 4320. (https://doi.org/10.1038/ ncomms5320)

Zhang J, Hatakeyama J, Eto K \& Abe S 2014 Reconstruction of a seminiferous tubule-like structure in a 3 dimensional culture system of re-aggregated mouse neonatal testicular cells within a collagen matrix. General and Comparative Endocrinology 205 121-132. (https://doi. org/10.1016/j.ygcen.2014.03.030)

Zhang X, Wang L, Zhang X, Ren L, Shi W, Tian Y, Zhu J \& Zhang T 2017 The use of KnockOut serum replacement (KSR) in three dimensional rat testicular cells co-culture model: an improved male reproductive toxicity testing system. Food and Chemical Toxicology 106 487-495. (https://doi.org/10.1016/j.fct.2017.05.001)

Received 5 September 2020

First decision 25 September 2020

Revised Manuscript received 22 February 2021

Accepted 2 March 2021 